\title{
Support of Mnemonics Strategies and Parental Involvement in the Development of Early Childhood Literacy
}

\author{
Nurul Mishbah \\ EarlyChildhood Education Department, Padang State University,Padang, Indonesia,nurulmisbah03@gmail.com
}

\begin{abstract}
One of the essential abilities to develop early on is literacy. Literacy is the foundation of the learning process and the key to learning success. Literacy skills become an early foundation for the mastery of various science and technology throughout the ages. Literacy skills are not the ability that children have in line with age increase but the ability to possess due to habituation or stimulation. Teachers with the right strategy play an important role in stimulating children. Mnemonics strategy is seen as a technique that can be used by anyone without having a special brain ability. The teacher's role is not enough to maximize the development of child literacy. In this case parental support is indispensable. With the right teacher strategy and parental involvement in providing stimulation and literacy experience, it is expected to maximize the development of child literacy skills.
\end{abstract}

Keywords: mnemonics, parental engagement, literacy

\section{INTRODUCTION}

Early age is the most important preliminary period along the growth range and the development of human life. At this time it was marked by various fundamental important periods in the life of the next child until the final period of development. Many of the concepts and facts in the find given the golden period explanation is in early age, where all potential children develop very quickly. Some concepts that are in early childhood are the exploration period, the identification period/imitation, the sensitive period, the playtime and the development period of the early stages. But on the other hand early childhood is at a critical time, that is the golden age of children will not be repeated in the next time, if the potential is not stimulated optimally and maximally at the early age. All aspects of child development must obtain maximum and optimal stimulation through meaningful learning activities for children involving parents, teachers and schools. (Suryana, 2013).

Among the important skills to be developed early is literacy. Literacy is the foundation of the learning process and the key to learning success. Literacy is key to a variety of science and technology. Whitehurst \& Lonigan (in Hapsari, et all, 2017:178) (Hapsari, Ruhaena, \& Pratisti, 2017) synthesise the knowledge, skills, and attitudes of preschoolers who became the basis of reading and writing called Early literacy skills. The implementation of literacy on early childhood education does not mean teaching reading and writing as well as elementary school level learning. Literacy in early childhood is done by providing stimulation and motivation and learning experience to the child to get used to the process of reading and writing. Early childhood teachers must be able to guide, assist and direct their children to develop literacy with the right strategy. Mnemonics strategy is a strategy to improve memory and have been used thousands of years ago. Mnemonics can be used by anyone including to develop early childhood literacy skills. Bakken and Simpson (2011) revealed that mnemonic techniques have proven to help individuals to recall information by making it more memorable, meaningful, and more concrete.

\section{DISCUSSION Literacy}

Literacy comes from the Latin language, which is literatus, meaning marked by letters, literate or educated (Toharudin, in Basyiroh, 2017, p. 121) (Basyiroh, 2017) lately, the term literacy appears to explain the development of children's early writing and natural reading skills. Gambrell \& Mazzoni (in Beaty, 2013) displays when researchers begin to observe and report the literacy activities of preschoolers, they find that children are involved in a variety of behavioral literacy behaviors, such as hearing stories, discussing stories, figuring stories, scribing "letters" on family and friends, writing their names, and making their own marks as prints.

According to Rohde (2015, p. 1) It is important to ensure that children acquire the early skills and awareness they need to become successful readers and writers. According to NAEYC literacy is an activity that is able to encourage children to develop as readers and writers so that it is in need of interaction with a person who controls literacy (Muzakki, 2018, p. 259). The interaction is the process of literacy that occurs the environment closest to the 
child can occur with the child with parents, and children and teachers. Cooper in (Susanto, 2018) stated that early literacy "... Involves all elements of the communication process: reading, writing, speaking, listening, viewing, and thinking. "Campana, Mills, \& Ghoting (in Djonov, Torr, \& Stenglin, 2018 , p. 10) developed a special defendant for the public library in the United States: initial literacy is what children know about communication, language ( Verbal and nonverbal), reading, and writing before they can actually read and write. It includes all the child's experiences with conversations, stories (spoken and written), books, and prints. Initial literacy is not reading teaching. It refers to laying a strong foundation so that when children are taught reading, they are ready.

Muzakki (2018, p. 261) presented a survey conducted by one of the United States Department of Education divisions showing that toddlers who used to read books by their parents could be more quickly acquainted with the alphabet. Other surveys show the success of toddlers in early literacy phases, such as writing their own name, reading or interacting with books, and counting up to numbers to develop critical thinking skills. From some of these opinions it can be concluded that early literacy is not to teach reading and writing but the process of preparing attitudes, experiences and skills of children to be ready to learn to read and write through interactions and processes Critical communication. A simple thing that has great influence for child literacy skills to familiarize children with reading books and reading activities.

\section{The Mnemonics Strategy}

According to Bakken \& Simpson (2011, p. 79) mnemonic strategy is a systematic procedure to improve memory and make information more meaningful. A mnemonics is a learning technique that helps aid the process of memory. A mnemonics helps to convert the storage of experienceand information from short term memory into long term memory (Woods, 2014)

Mnemonics strategy is any memory improving strategy can, but in its more specific meaning, mnemonics to artificial memory aids such as stories, rhymes, acronyms, and more complex strategies involving verbal mediators or visual imagery, such as the journey method or method of loci, the pegword method and the keyword method (McPherson, 2018).

Keysan, et al (2013), investigated the effects of selected presentation techniques including the keyword method, the peg word method, the loci method, argument mapping, concept mapping and mind mapping on L2 vocabulary comprehension and production.

Woods (2014) explained the various mnemonics devices used to create popular memory aids and triggers. They are:

1. Acronym: a created word where each letter serves as a cue for an idea or name one needs to remember

2. Acrostic: a created sentence where the first letter of each word serves as a cue for an idea or name one needs to remember
3. Alpha-Numeric Conversion: Simply a way for study and learn the ordinal positions of the letters in the alphabet.

4. Alpha-Acoustic-Image Correspondence: This mnemonics device is a peg system in wich a letter of the alphabet is given a corresponding image of something names as the alphabetical letter.

5. Deka-Numeric- Letter PEG: is a mnemonic device where the ten basic digits $(0,1,2,3,4,5,6,7,8$, and 9) are substituted with a logically assigned constant letter of the alphabet.

6. Phono-Deka Numeric PEG: is another mnemonic strategy used to help identify information relevant to positions of designated order. Memory experts created this system to serve as a very popular way to convert abstract numbers into concrete images.

7. Rhyme-Rap Story Technique: is a mnemonic that integrates information one is trying to retain into a song, catchy story, rap, or poem format.

8. Language Arts Codification Technique: is a device where the letters and punctuation marks in a designed mnemonic are written in a pictographic fashion employing artifice to highlight or symbolize a key fact that one is attempting to remember

9. Character Codification Process: is a mnemonics device where the number of letters appearing in each word of designed mnemonic is representative of a key digit that is found in a specific formula, date, phone number, or other data one wishes to remember.

10. Deka-Number- Shape Technique: is another PEG method. It is a strategy that pegs new information with images and shapes that resemble the numbers from one to ten.

Some techniques in mnemonic strategies can be combined with one another. In early childhood education unknowingly teachers of early childhood have done some techniques in mnemonic strategies such as reading stories, repeating story content, guess game letters, words or pictures, singing, rhymes, and Pat variations. But the ability and experience of early childhood literacy will be increased and meaningful when this strategy can be used optimally.

\section{Parental Involvement}

Parents have an important role in child education. Because the family environment in this case parents is the first and foremost educator for the child. The Tri Education Center, initiated by Ki Hadjar Dewantara, puts the family as one of the educational environments that can contribute to the development of children. Parental involvement in education is defined variably by some figures, among them Hawes \& Jesney (in the Diadha, 2015) reveals that parental involvement can be interpreted as a parental participation in the education and experience of his children. Another opinion expressed by Morisson (2012, p. 375) Parental involvement is a process of helping parents and family members use their ability to benefit oneself, children, and early childhood programs. Besides DiNatale (in Beaty, 2013, p. 456) states that one of the most accurate predictors of achievements is not family income or parental education level, but the level at which parents believe they can be an important resource in 
their child's education and are involved in the community and communities.

From some of these opinions can be concluded that parental involvement is the participation and contribution and collaboration of parents and teachers in the education process and help the achievement of all aspects of child development

In parental involvement, readiness becomes the main thing as a first step in the Early Childhood education program and teachers should provide an opportunity for parents to engage at all levels of this from low to high level. Parents as the first person close to the child know most about the child's development and the child's condition, what is in love and hate by the child, as well as children's hobbies and ideals are included in improving literacy skills. Reese et al (in Nuraeni, 2016, p. 247) states that there are three things parents can do to improve the language and literacy of early childhood children. First is the parent reads the book together with the child, the second is the parent does a conversation with the child, and the third is the parent-child doing the activity of writing together. All three are effective ways to develop the language and literacy skills of early childhood Other than that anything else that parents with children can do in literacy stimulation include:

1) Read Storybook/fairy tale,

2) Invite a child to a library or reading garden or bookstore

3) make the book a gift

4) Write the child's wish list

5) Read the writing on the pamphlet along the path to a place/destination

6) Ask the child to draw his or her experiences in the school or other activities and tell the picture

7) Read the writing on plastic packaging such as brands, food composition.

With parental involvement in stimulating and creating a variety of literacy experiences for children is expected to improve early childhood literacy skills.

\section{CONCLUSION}

Early age is the most important preliminary period along the growth range and the development of human life. Mnemonics strategy is seen as a technique that can be used by anyone without having a special brain ability. The teacher's role should be maximized by parental support. With the right teacher strategy and parental involvement in providing stimulation and literacy experience, it is expected to maximize the development of child literacy skills.

\section{REFERENCES}

[1] Bakken, J., \& Simpson, C. G. (2011). Mnemonic Strategies: Success for the Young-Adult Learner. The Journal of Human Resource and Adult Learning Vol. 7, Num. 2, December 2011, 79-85.

[2] Basyiroh, I. (2017). Program Pengembangan Kemampuan Literasi Anak Usia Dini. Tunas Siliwangi Vol.3, 120-134.
[3] Beaty, J. J. (2013). Observasi Perkembangan Anak Usia Dini. Jakarta: Kencana.

[4] Diadha, R. (2015). Keterlibatan Orang Tua Dalam Pendidikan Anak Usia Dini di Taman Kanak-Kanak. Jurnal Ilmu Pendidikan dan Pengajaran, Vol. 2 No. 1, 61-71.

[5] Djonov, E., Torr, J., \& Stenglin, M. (2018). Early language and literacy Review of research with implications for early literacy programs at NSW public libraries. New South Wales: Department of Educational Studies, Macquarie University.

[6] Hapsari, W., Ruhaena, L., \& Pratisti, W. D. (2017). Peningkatan Kemampuan Literasi Awal Anak Prasekolah melalui Program Stimulasi. Jurnal Psikologi Volume 44, 177-184.

[7] McPherson, F. (2018). Mnemonics for Study. Wellington, New Zealand: Wayz Press.

[8] Morrison, G. S. (2012). Dasar-dasar Pendidikan Anak Usia DIni. Jakarta: Indeks.

[9] Muzakki. (2018). Peran Orang Tua dalam Menumbuhkan Budaya Literasi pada Anak Usia Din. Al Hikmah Proceedings on Islamic Early Childhood Education (pp. 259-264). Tuban: Sekolah Tinggi Agama Islam Al Hikmah.

[10] Nuraeni, A. (2016). Peran Orang Tua Dalam Pengembangan Literasi Dini Anak Kelompok B Di Gugus 7 Mangunan Dlingo Bantul. Jurnal Pendidikan Anak Usia Dini Edisi 3 , 245-256.

[11] Rohde, L. (2015). The Comprehensive Emergent Literacy Model: Early Literacy in Context. SAGE Open, $1-11$.

[12] Suryana, D. (2013). Pengetahuan Tentang Strategi Pembelajaran Sikap dan Motivasi Guru . Jurnal Ilmu Pendidikan, Jilid 19, Nomor 2, 196-201.

[13] Susanto, A. (2018). Pendidikan Anak Usia Dini Konsep dan Teori. Jakarta: Bumi Aksara.

[14] Woods, C. (2014). Mnemonics: A Strategy For Teaching and Learning. United States of America: Charles A. Woods. 